\title{
Decentralised renewable energy and prosperity for Lebanon
}

\author{
Henrietta L. Moore ${ }^{*}$, Hannah Collins ${ }^{1}$ \\ Institute for Global Prosperity, Floor 7, Maple House, 149 Tottenham Court Road, London, W1T 7NF, United Kingdom
}

\section{A B S T R A C T}

This paper reviews and updates the current renewable energy (RE) policy landscape in Lebanon. The focus is on opportunities for decentralised RE to not only address Lebanon's insufficient energy supply but the compounding challenges of mass displacement and changing climate. In recent years Lebanon has made great progress in RE despite the ongoing regional turbulence but more could be done to utilise the countries abundance of renewable resources, growing population and entrepreneurial acumen. Energy policy from a prosperity perspective is informed by the role public services play in people's self-defined aspirations of what it means to live a good life. With the policy support from above, locally managed and decentralised RE supply has potential to not only address the energy crisis but also mitigate the impacts of mass migration and climate change, setting Lebanon on a path to a sustainable and prosperous future.

\section{Introduction}

For the most part there is agreement on the need to transition to sustainable economies but little agreement on what the transition and the corresponding policies could look like. By looking at energy policy beyond just the macroeconomic questions and contribution to infrastructure development, we look at the benefit of transformations of energy systems in terms of people's quality of life and the role public services play in building capacities and capabilities. This is important for countries that have sustained systemic shocks, such as war and mass displacement, and are also experiencing the threat of the climate emergency. When devising policies for transformation through complex challenges it is important to keep in mind the need for citizen-based focus on quality of life. This paper looks at what is happening in Lebanon and why renewable energy, in its nature, addresses carbon emissions and future prosperity.

Traditionally, literature on Lebanon's energy policy has focused on classical economic analysis, but there is a shift in global understanding, away from traditional economic models which emphasise economic growth to prosperity (Jackson, 2011; Moore, 2015; Stiglitz et al., 2010). Prosperity encapsulates what we value and how we can all flourish in culturally and historically specific ways within the confines of our planet's resources. The strength and challenge of global prosperity is in its foundation; that there are diverse ways to flourish and no single model of development. We need to engage with diversity to create inclusive sustainable change, tying social value to economic value (Moore, 2015). In the context of Lebanon, a prosperity lens is crucial to create energy policy that can address the needs of a population that has dramatically increased due to mass-displacement (Yassin, 2018), and is facing the current and predicted impacts of climate change (Ministry of Environment, 2011; Ministry of Foreign Affairs of the Netherlands, 2018; ANND, 2017).

To bring the energy policy landscape up to date in Lebanon we explore the current policy frameworks, the drivers that are shaping it and the RE projects that have already been implemented. Prosperity for Lebanon is dependent on a RE transition, inextricably linked to public services. This complex inter-dependency means that a reliable energy supply would improve the wellbeing, employability, safety, health and education for residents of Lebanon. Energy policy in Lebanon should focus on decentralisation, informed by Lebanon's citizens who are already engaging in RE alternatives to the energy crisis.

\section{Challenges for energy policy in Lebanon}

The impact of climate change covers the entire economy of Lebanon and all aspects of the environment which is vulnerable to the rising sea levels and heat waves (Ministry of Foreign Affairs of the Netherlands, 2018). By 2020 Lebanon is expected to face chronic water shortages (ANND, 2017) with some estimating sea levels to rise $60 \mathrm{~cm}$ in the next 30 years (UNDP, 2019a). Water shortages and heat waves will add

\footnotetext{
* Corresponding author.

E-mail address: igpdirector@ucl.ac.uk (H.L. Moore).

1 Independent scholar.
} 
additional strains to a struggling energy system. Projections for temperature rises of between $1 \mathrm{C}$ to $3 \mathrm{C}$ by 2040 are estimated to lead to an annual increase in electricity consumption for cooling between $9.04 \%$ and 28.55\% (Ministry of Environment, 2011).

There is a mixed response in Lebanon to the changing landscape of energy investment and the IPPC (2018) deadlines on climate change. Lebanon is searching for its first oil and gas reserves but has committed to reducing its greenhouse gas emissions by at least $15 \%$ by 2030 and up to $30 \%$ with the conditional support of international actors (UNDP, 2017). The electricity sector in Lebanon is responsible for over $53 \%$ of the national greenhouse gas emissions (UNDP, 2017) and imported fossil fuels still account for $98 \%$ of all energy supply and provision (OECD/IEA, 2014). The current model of energy provision is failing to acknowledge the prosperity of future generations.

Electricite du Liban (EDL) holds the monopoly of energy supply in Lebanon. It is a vertically integrated national utility accountable to the Ministry of Energy and Water (MoEW) which is responsible for policy formulation for electricity, fuel and water sectors. Overall responsibility rests with the Council of Ministers (CoM) chaired by the Prime Minister and includes ministries that represent the major political parties in the country (World Bank, 2019).

The electricity sector is a huge financial burden on Lebanon's public finances. In 2017 EDL made an operating loss of USD1.4 billion, with sector subsidies between 2008 and 2017 aggregating to account for close to half of Lebanon's overall external debt (World Bank, 2019). EDL's tariffs are based on 1996 fuel cost of USD23 per barrel of oil and only cover $37 \%$ of average operating cost in 2018 . Despite these large subsidies, electricity supply is insufficient to meet demand. Inadequate energy infrastructure and supply has resulted in endemic power outages. EDL utility only covered about $47 \%$ of the electricity demand in 2018. The power gap is estimated at about $1 \mathrm{GW}$ equalling daily cuts for $3 \mathrm{~h}$ in Beirut and up to $17 \mathrm{~h}$ in the Bekaa Valley (World Bank, 2019).

The unreliability of the energy services has become inherent in everyday life in Lebanon. 'Illegal' connections to private diesel generators have been normalised to maintain the necessary electricity to reach basic requirements for households and businesses (Abi Ghanem, 2018). The percentage of 'illegal' connections to the grid result in a financial burden on the national economy exceeding USD330 million per year (AEMS, 2017). In 2017, 66\% of Lebanon's households relied on diesel generators to back-up power supply, with over $46 \%$ of households paying $8.4 \%$ of their income to secure electricity (UNDP-CEDRO, 2018a). Residents pay a double electricity bill; one for EDL and the other for back-up generation, almost twice that of EDL, which results in the highest electricity bills in the region (Fardoun et al., 2012). Neighbourhoods are allocated one private energy provider, with the backing of politicians, who do not face competition and can set their own fees (Mohsen, 2012). They are further legitimised through local tariffs aimed at them. New housing blocks are built with space for generators so new tenants have little choice but to enter accept this informal arrangement (Verdeil, 2016; Abi Ghanem, 2018). This contractual and physical entanglement of private generators in daily life reflects the adaptability of the population creating their own access to this intrinsic service.

Since the civil war Lebanon has relied heavily on energy imports. The dependence on oil imports not only contaminates the environment it increases the vulnerability of the Lebanese economy to fluctuating oil prices (UN ESCWA, 2018). There is global consensus (UN Sustainable Development Goal 9; UNDP, 2019b) that energy is crucial not only as a basic requirement to live a good life, but across all economic activities, as drivers of new industries and innovation and for information and communication technologies. Electricity shortages are a feature of daily life that undermine the social contract, recovery will not be possible without a 24-h energy supply and future sustainable prosperity is dependent on that supply coming from renewable sources.

Compounding this is the fact that twenty-five percent of people living in Lebanon are displaced people from the Syrian civil war, the highest percentage refugee population of any country in the world. This does not include the 449957 registered Palestinian refugees ${ }^{2}$ (UNRWA, 2014). While the inadequate energy supply predates the Syrian civil war significantly ${ }^{3}$ the influx of people not only strains the system even more, it means that like the Lebanese, displaced people in Lebanon in both formal and informal settings are not obtaining the required electricity to operate basic household appliances. Governments and international actors recognise that the 'refugee crisis' is not a short-term emergency, but more could be done to implement policies to build energy resilience in communities. New and existing models of energy delivery in Lebanon must recognise the challenge of climate change and people's energy needs across varied contexts, considering socio-economic conditions and self-defined aspirations for prosperity.

\subsection{RE technology and policy in Lebanon}

Lebanon has achieved a great deal in recent years, from a country with no RE vision to a regional sustainability hub with renewable and energy efficiency targets (LCEC, 2016). The landscape of energy policy in Lebanon is complex incorporating different actors and drivers. The rise of RE technology can be directly linked to certain policies and projects highlighting the crucial role of government and policy makers in supporting a RE transition.

The Lebanese Centre for Energy Conservation (LCEC) was initiated as a joint project between the MoEW and the UNDP in 2002. Their main objective was to create a national energy agency to push for energy efficiency and they are now the national energy agency for Lebanon affiliated to the MoEW but with a financially and administratively independent statute (LCEC, 2018). The first milestone for the development of RE in Lebanon came in 2010 when the MoEW committed to the Policy Paper for the Electricity Sector (PPES) to launch, support and reinforce public, private and individual initiatives to adopt RE, and to reach $12 \%$ of electric and thermal supply from RE by 2020. In 2018 the Government of Lebanon (GoL) further pledged a switch to natural gas and RE in their Capital Investment Plan (CIP; GoL, 2018) and extended the target to $30 \%$ of electricity and heat consumption through renewables by 2030 (IRENA, 2019).

The National Energy Efficiency and Renewable Energy Action (NEEREA) is a national financing mechanism initiated in 2010 by Lebanese Central Bank (BDL) with support from the European Union and technical assistance from LCEC. It provides incentives for RE projects through interest free and long-term loans (LCEC, 2019a). The NEEREA supports the financing of new and existing energy efficient, RE and sustainable building projects. It allows private sector entities to apply for subsidised loans for environmentally friendly projects. By the end of 2017690 loans had been approved through the NEEREA totalling USD405 million. However, financing for largescale RE projects are constrained as the NEEREA only finances RE projects for individual consumption, not for independent power production (IPP; UN ESCWA, 2018).

Following on from the country's National Energy Efficiency Plan (NEEAP 2011-2016) Lebanon was one of the first countries to develop its own National Renewable Energy Action Plans (NREAP) 2016-2020. The NREAP 2016-2020 clarifies the individual targets for different RE technologies needed to reach the $12 \%$ target by 2020 (LCEC, 2016, Table 1.). Implementation of the NREAP 2016-2020 needs between USD1320 million and USD3166 million while the direct cumulative

\footnotetext{
${ }^{2}$ Most Palestinian refugees in Lebanon live across 12 camps where they have no right to work (UNRWA, 2014). They are left out of RE initiatives as it is government policy that no permanent infrastructure should be installed in informal settlements.

3 The grid has yet to be restored since it was severely damaged during the Lebanese civil war (1975-1990) and some claim the electricity sector has always struggled to provide 24-h electricity to Lebanon's inhabitants (Abu-Rish, 2015).
} 
Table 1

Percentage contribution for each energy source to the $12 \%$ renewable energy by 2020 goal as laid out in NREAP 2016-2020 (LCEC, 2016).

\begin{tabular}{ll}
\hline Energy Source & Contribution to the $12 \%$ goal \\
\hline Hydropower & $3.24 \%$ \\
Wind Power & $2.06 \%$ \\
Biomass (including waste-energy) & $2.50 \%$ \\
Solar energy (PVs, CSP, SWHs) & $4.20 \%$ \\
\hline
\end{tabular}

savings for the economy are estimated at USD319 million (UN ESCWA, 2018). The NREAP projects implemented by 2020 will provide an extra $1890 \mathrm{~h}$ of electricity with the first to benefit those people in Lebanon who are least able to afford the financial burden of the high electricity bills. Environmentally, full implementation of the NREAP will reduce Lebanon's yearly carbon dioxide emissions by $11.25 \%$ (UN ESCWA, 2018). The NREAP 2021-2025, with updated targets, is due to be released this year (IRENA, 2019).

Today RE contribution to total power production in Lebanon is estimated at between $4 \%$ and $6 \%$ mainly via hydropower. The only forms of energy produced within Lebanon come from solar water heaters and hydroelectric plants (UN ESCWA, 2018). In 1976 approximately $70 \%$ of the total electricity production came from hydroelectricity (LCEC, 2016). The development of hydropower plants depends on the construction of dams, controversial as they threaten Lebanon's biodiversity (Kranz, 2019). Now the water network is so damaged that approximately $48 \%$ of the water gets lost before reaching the end user making constructing more dams without repairing the system wasteful (El Solh, 2016). Despite this, dams are continuing to be built hydropower is estimated to make a significant contribution to the $12 \%$ target (Table 1.)

Wind power has reached grid parity as a viable and cost-competitive choice for electric power generation and is set to contribute $2.06 \%$ to the $12 \%$ target. The National Wind Atlas of Lebanon estimated a wind potential of at least 1500 MW (UNDP, 2011 in Khoury et al., 2016). Earlier this year Lebanon signed its first power purchase agreement (PPA) for wind energy in Akkar with the combined capacity of 200 MW by 2020 (Amine, 2018). Technical expertise as well as large investments are needed to implement large-scale wind farms and require significant government support. Smaller-scale wind farms or single turbines would help overcome land constraints, engage citizens and increase acceptance of the technology (UNDP-CEDRO, 2019).

Biomass, with a focus on waste-energy, is set to cover $2.5 \%$ of the $12 \%$ target (LCEC, 2016). Biomass is a biological material derived from living things which can be used directly via combustion to produce heat, or indirectly after converting it to biofuel (El-Jamal, Ibrahim and Ghandour, 2014). Biomass is the fourth largest energy source and is important as it can produce different forms of energy and resources are common around the world (LCEC, 2016) and offers synergies with other sectors such as waste management, water treatment and forestry (UNDP-CEDRO, 2019). Lebanon has a relative abundance of bioenergy resource as one-third of the country's land is arable. Utilising local resources and biofuels in is an important component of a RE transition for Lebanon that the government is failing to recognise.

The solar photovoltaic (PV) sector is now established with over 100 competitive companies in Lebanon with potential for further growth. Solar PV energy production is in abundant supply in Lebanon with around 300 days of sunshine per year, for eight to $9 \mathrm{~h}$ each day (Berjawi et al., 2017). Given that most electricity rationing in Lebanon occurs during the day solar energy offers a sustainable alternative to cuts and diesel generators. Solar PV plants can be complemented with wind power given that when the sun is not shining the wind is blowing.

Solar water heaters (SWHs) are the most developed RE technology in Lebanon which has been gaining momentum since the 2010 to achieve "a solar water heater for every household," (Bassil, 2010). The NEEAP 2011-2015 laid out a financing scheme for the SWH market (LCEC,
2016). Private banks, initiated through BDL, offer five-year, interest free loans for residential SWHs (that do not exceed \$5000) and the MoEW contributes $\$ 200$ to cover capital costs. SWH projects that exceed $\$ 5000$ can apply for the NEEREA loan. These loan schemes created momentum in the Lebanese SWH market which has more than doubled since 2010 (LCEC, 2019b). Thirty-eight percent of the SWH systems installed in Lebanon were partially or totally manufactured in Lebanon (UNDP-GEF, 2014) showing potential for further market development in other RE systems.

In 2011 EDL adopted a net-metering policy which supports the expansion of solar energy in Lebanon to households and expanded to communities in 2016. Net-metering allows for a two-directional flow of energy, from the grid to the customer and from the customers RE facility to the grid using a bi-directional meter (Berjawi et al., 2017). EDL does not pay for the net production produced by consumers but credits the excess production to the next bill. More than 50 projects are connected to the net-metering network but due to the lack of meters at EDL net amounts must be calculated manually limiting the effectiveness of the policy (UN ESCWA, 2018).

Solar energy is to cover one-third of the $12 \%$ target (Table 1.). From 2010 to 2017 solar PV capacity rose from around 0.35MWp to over $35 \mathrm{MWp}$, averaging an annual equivalent growth of $100 \%$ (UNDP-DREG, 2018). Solar PV generation increased from 35,000 MWh in 2016 to 53, $000 \mathrm{MWh}$ in 2017 constituting $0.35 \%$ of the annual electricity generation by EDL (UNDP-DREG, 2018). The Beirut River Solar Snake comes as part of the NEEAP 2016-2020 plan to install 200 MW of solar farms by 2020. It is the first solar PV farm at a national level with a total planned output of $10 \mathrm{MW}$. The private sector designed, built and transferred the RE generation plant with government support. Only the first stage of the project has been completed adding an extra $1 \mathrm{MW}$ of electricity to the grid (Machnouk et al., 2019). In 2017 and 2018, the MoEW launched two consecutive bids for 12 and 24 PV farms respectively (of 10-15 MW each). A new bid has been launched for three PV farms (of 70-100 MW each) which includes plans for the first electricity storage of $70 \mathrm{MWh}$ (Machnouk et al., 2019).

Pierre El Khoury, president of the LCEC, 2017, said in 2017 that the $12 \%$ by 2020 target was achievable (The Business Year, 2017). But solar PV alone could cover at least the daily power peak load, far outreaching the LCEC 2020 target (Berjawi et al., 2017). Lebanese policy makers underestimate the potential of solar PV in improving energy security, energy billing and reducing the impact of fossil fuels for electricity generation (Berjawi et al., 2017).

Interlinkages exists between the main actors driving the RE sector in Lebanon, such as EDL, MoEW, LCEC, BDL and the UN. On paper they work together and pledge support to the $12 \%$ by 2020 target in the NREAP 2016-2020 and through the NEEREA loan scheme. The energy monopoly held by EDL means that all actors working in the field must coordinate with EDL. In the NREAP 2016-2020 the LCEC committed to publishing yearly follow-up reports on the progress of implementation (LCEC, 2016). This would show which actors were driving RE progress, how it is coordinated and how it was being measured and implemented. The progress report for 2017-18 have not been produced by LCEC.

Steps have been taken to develop Lebanon's energy sector towards renewable sources, at least to achieve the $12 \%$ by 2020 . There is recognition within different sections of government (through the $12 \%$ target goal; NREAP 2016-2020; the NEEREA loan scheme; and the CIP) and from public (through the uptake of SWHs) and private sector (through private banks loans for SWHs, the financing of wind farms in Akkar and the Beirut River Solar Snake) that RE is the way forward. While there is some coordination between the big players of RE in Lebanon, it is apparent that a lack of legal framework is inhibiting the sector from flourishing and limiting it to small-scale projects rather than a concerted nation-wide effort to transition to RE. 


\subsection{Constraints and opportunities for a $R E$ transition in Lebanon}

The main barrier to full deployment of RE technologies is the lack of components and clarity within the existing and outdated institutional and legal frameworks, with reforms hindered by political fractionalisation. Regulations are based on industrial traditions and codes, not up to date with sector developments. Delays to implementation of legal framework to privatise, liberalise and unbundle the sector have meant that only one wind power programme signed a PPA, under a law that has since expired (UN ESCWA, 2018). This means that decrees that give EDL the monopoly in generation, transmission and distribution are still being applied. A legal regulator to set prices and liaise between government and private power producers has not been appointed. Currently, the CoMs is tasked with assigning PPAs. It is not clear which legal process the GoL will deploy and this uncertainty is delaying major investments in utility-scale RE. A critical challenge for Lebanon will be managing governance and transparency in the energy sector but the government's recent request to join the Extractive Industries Transparency Initiative is a step in the right direction (Machnouk et al., 2019).

Low and not cost-reflective electricity tariffs are a barrier to deployment of RE because of the long amortization period. EDL cannot increase the tariffs until infrastructure and the grid are reliable, but at the same time EDL does not have the finances to improve the systems reliability (UNDP-CEDRO, 2019). EDL will be the main customer for all large-scale RE projects, but their financial deficit and bankability problems increase the risk of investment. There is no dedicated department with EDL for incorporating RE into the national grid and no grid codes exist internationally that could be adopted (UN ESCWA, 2018). We need to look beyond just recalibration of the Lebanese energy system in the form of institutional reforms which are slow to implement, to the way decentralised, local production of energy can provide the population with a high standard of reliable, affordable and renewable energy.

Another constraint to a RE transition for Lebanon is the vested interest throughout the economy in oil imports and the entrenched nature and power of the private generator owners. Some estimate the private generator industry to be worth USD1 billion (Rose, 2018). This gives the owners power and influence over lawmakers in an already fraught political sphere where key energy policy decision makers include the Lebanese Oil Installations Directorate and the Lebanese Petroleum Administration (World Bank, 2019). The entanglement of the generators in everyday life and within the distinct socio-political divides is a barrier to new systems of delivery and can inhibit mobilisation against the current energy supply in Lebanon (Abi Ghanem, 2018). Energy policy focussed on RE needs to acknowledge this complexity and to engage with and enhance the capacities of both old and new players in the energy business.

The prospect of natural resource discovery has generated a great deal of investment interest and political debate (Fattouh and Mahadeva, 2016). Domestic gas could reduce import dependence and emissions. Commissioning of an investment programme for construction of a number of gas-based power plants through the private sector, primarily in Salaata, Zahrani and Deir Ammar, are expected to be installed by 2021 (World Bank, 2019). The gas market is expected to initially be dominated by gas imports that will eventually partly be replaced by indigenous gas. Gas streams will enter the Lebanese market at different geographic locations and on different contractual terms but there is no developed legal or physical infrastructure to manage market ownership and structure. The AUB Policy Institute (2018) suggest that the GoL needs to play a central role in regulating the gas market. There is potential for a hybrid-energy system here that allows for private sector investment in gas and RE technologies but this needs to be connected to a broader agenda and policy for long-term prosperity in Lebanon.

An obstacle to high penetration of RE is land availability in Lebanon. Tfail, an inland region in the Bekaa Valley on the border with Syria, has been shown to include around $13 \mathrm{~km}^{2}$ of elevated flat lands with high levels of solar irradiation (Ayoub and Boustany, 2019). An examination of the technical and economic feasibility of a $300 \mathrm{MW}$ solar PV plant in Tfail demonstrates robust technical and financial incentives with Levelized Cost of Electricity ranges between 4.2 to 5.3 cents $/ \mathrm{kWh}$ of electricity produced. The average annual energy generation over the project's lifetime is around $600 \mathrm{GWh}$ /year. Given the location, such a project could play a role in potential electricity swap deals and trading with the Syrian grid in the future (Ayoub and Boustany, 2019). This pre-feasibility research is important as it provides information for attracting investors and it has been reported that European Bank for Reconstruction and Development is seeking consultants for a feasibility study for the project (Bellini, 2019).

While energy supply in Lebanon is insufficient to meet the populations basic needs and the current RE contribution to total supply is minute, for a RE transition to be successful people must also be willing to modify their lifestyle through reducing and adapting power consumption $^{4}$ (Khoury et al., 2016). For a RE transition to be successful insights into energy options must be made available to consumers so they can make informed decisions for themselves and the environment. There is potential in the Lebanese public's adaptability to changing their energy supply (Abi Ghanem, 2018). The higher the amount people pay for informal generators the more willing they are to pay for RE options so designing RE programmes that displace diesel generators have a better chance of success and can attract more funding (UNDP-CEDRO, 2015).

Unemployment in Lebanon is subject to a wide-range of estimates with an absence of reliable data. Between 2007 and 2017 total unemployment estimates ranged between $6.4 \%$ to $25 \%$ (ECOSOC, 2019). While in 2018 the Lebanese President cited a figure of $46 \%$ unemployment due to the presence of displaced Syrian (The Daily Star, 2018, March 30). Lebanon has identified agriculture, infrastructure and environment as sectors with potential for employability for displaced people making investment and action in RE infrastructure an employment solution for people in Lebanon. Analysis of the RE technology value chain in Lebanon estimates that 20,000 jobs could result from the deployment of RE technologies by 2021, the bulk being in the solar PV sector (UNDP-CEDRO, 2019).

A study by IRENA and UN ESCWA, 2018 found strengths for local manufacturing in Lebanon, where industries related to electronics, steel, aluminium and plastics are well developed and can play a role in stimulating the RE industry. Furthermore, university programmes associated with RE research mean that the technical know-how is available and there is good potential for local integration and manufacturing of RE technology in Lebanon (IRENA and UN ESCWA, 2018).

With the absence of reliable and continuous electricity decentralised $\mathrm{RE}$ systems are among the easiest to deploy, are cost-effective and sustainable. The costs of RE are less than that of diesel generators and less than the average costs EDL pays for energy distribution and generation (IRENA and UN ESCWA, 2018). While the legal and political hurdles are constraining large-scale RE projects, the opportunities for a RE transition in Lebanon and future prosperity are in decentralised community-led projects.

\section{RE successes in Lebanon}

By looking to the RE successes in Lebanon, future energy systems will need a combination of on- and off-grid hybrid technology, will be decentralised and will come from the ground up. Not only do they create a reliable energy network, they have knock-on benefits through new value chains and benefit the education, health and safety of communities.

In partnership with the MoEW, EDL, the Council for Development

\footnotetext{
${ }^{4}$ This is not just a Lebanese problem, changing mindsets in the age of consumption is a significant hurdle towards RE transitions worldwide (Loveday et al., 2008; Von Borgstede, Andersson \& Johnsson, 2013; Shi et al., 2019).
} 
and Reconstruction and LCEC, the UNDP is managing the country energy efficiency and RE demonstration project for the recovery of Lebanon (CEDRO) since 2007. Now in its 4th phase, CEDRO aims to find cost effective and environmentally beneficial ways to transform the energy system (UNDP-CEDRO, 2018b). Since 2007 more than 100 small-scale RE applications have been implemented nationwide including PV, micro-wind, solar PV street lighting, SWHs and ground source heat pump projects to both host and refugee populations.

In 2018 CEDRO completed 'Village 24' Initiative the first community-led RE system in Lebanon (UNDP-CEDRO, 2018b). Approximately 100 households in Kabrikha in Southern Lebanon signed up to the scheme entirely powered by $250 \mathrm{kWp}$ solar PV coupled with diesel generators. It is the first community to utilise the net-metering policy. The electricity expenses have dropped $30 \%$ and the village no longer experiences power cuts (EUinLebanon, 2018). The initiative allows a community-scale RE powerplant to plug into the separate local grid that is owned and operated by the municipality when the power is cut, and then allows the same RE power to plug into the utility network when national power is available (UNDP-CEDRO, 2018b). It is expected that this model will lead to the implementation of other community-led RE systems (whether solar, wind or bioenergy) that provide energy security, environmental benefits, community cooperation and economies of scale (UNDP-CEDRO, 2018b).

Historically, Lebanon has been known for its entrepreneurial acumen (Ahmed and Julian, 2012). Data from the Global Entrepreneurship Monitor (2019) for 2018 shows that $21.6 \%$ of 18-64-year olds are established business owners, $24.08 \%$ are either a nascent entrepreneur or owner-manager of a new business, and $42.01 \%$ see good opportunities to start a business in the place they live. But entrepreneurs in Lebanon are constrained by high electricity costs and unstable supply as well as the hybrid-political order that can channel entrepreneurial talent into bribery and lobbying (Stel and Naude, 2016). The reinforcement of family-owned business and entrepreneurs with connections to government (Stel and Naude, 2016) limits the potential for new RE entrepreneurs by limiting the diversity of ideas and knowledge.

With new generations coming to age there is a global shift in the social contract, seen in the Extinction Rebellion movement and the likes of Greta Thurnberg, decisions must be made that acknowledge and account for the planet's finite resources. The millennial generation constitutes approximately $20 \%$ of the Lebanese population (Youth Policy, n. d.). Lebanese youth are challenging the status quo (Krastrissianakis et al., 2019) with the popular, spontaneous and leaderless October 2019 mass proests further attesting to this, showing the potential to generate action to change the energy sector. They have already played as essential role in the growth in Lebanese civil society (AbiYaghi et al., 2017) and are set to become power players in the region in the next 15 years. The millennial generation have grown up with power cuts as a daily presence and are finding creative ways to solve the energy crisis utilising the potential for RE technology. Lebanese based social enterprises which offer RE solutions are contributing to the growth in the solar energy industry. For example, millennial run OTB Consult partnered with Greenpeace to train young Lebanese and refugees living in Lebanon with the skills to enter the solar energy market (Greenpeace, n.d.). Lebanon's entrepreneurs have the capability to contribute to RE provision, supporting the rebuild of communities, the country and the next transformation phase that will be fuelled by the rise of robotics and artificial intelligence.

\section{Policy recommendations and conclusion}

The current energy situation in Lebanon is not only a heavy burden macroeconomically but on new and old resident's quality of life and future prosperity. Enabling policies are needed to ensure effective innovation, supply and consumption of renewable technologies. Policies must continuously adapt to the changing market conditions to ensure greater cost-competitiveness. The GoL should adopt and enforce more aggressive targets for RE to contribute to the 1.5C IPCC target. The current targets outlined in the NREAP are unambitious and do not reflect the successes and growth of the RE sector potential (UNDP-CEDRO, 2019). Lowering taxes on RE products and adopting a grid code for the Lebanese context would allow the industry to flourish.

The institutional challenges of EDL must be addressed by adjusting tariffs to reflect actual costs and by encouraging new expertise into EDL through regular employment processes. The use of another agency attached to MoEW could work as a buffer customer for RE projects (UN ESCWA, 2018). Institutional and legal reforms need to be implemented to encourage private sector investment in $\mathrm{RE}$ infrastructure.

Until this urgent action is implemented decentralised distribution of RE offers a pathway that does not only hinge on government performance. A hybrid model of local ownership could help redefine energy citizenship and encourage people to engage with issues of energy access and payment. Community ownership is already a common ownership model in Lebanon, with buildings collectively buying generators to share, indicating there is traction for change and opportunities for decentralised approaches (Institute for Global Prosperity, 2019).

There needs to be policy recognition and research into the entanglement of energy provision shaping people's lives. The Issam Fares Institute proposes that the best strategy to address private generator owners would be to involve them in the process of transitioning the economy to RE (Dziadosz, 2018). A transition would include diversification of energy supply, energy demand management and energy trade, particularly intra-regionally. When looking for pathways to transformation it is essential we break down the consumer versus producer binary or the state versus community dichotomy, coming up with new solutions to the energy crisis premised on citizen control over their own lives and the resources of their communities. Energy policy should reflect this.

Decentralisation of RE systems changes the dynamic of how we think about energy and may help to change the way we use it. New forms of localism are taking hold around the world that are an opportunity for RE transitions. Local authorities need to be able to play an active role in controlling, spreading and efficiently using RE resources within their communities but this requires policy support from above.

\section{Funding}

This research was funded by the Economic and Social Research Company (ESRC) under the Global Challenges Research Fund (GCRF) as part of the RELIEF Centre at University College London. The founder had no role in study design, interpretation, writing and publication.

\section{Declaration of competing interest}

None.

\section{References}

IRENA \& UN ESCWA, 2018. Evaluating renewable energy manufacturing potential in the Arab region: Jordan, Lebanon and United Arab Emirates. Retrieved from: https ://www.unescwa.org/sites/www.unescwa.org/files/publications/files/evaluatin g-renewable-manufacturing-potential-arab-region-english.pdf. (Accessed 12 August 2019).

Abi Ghanem, D., 2018. Energy, the city and everyday life: living with power outages in post-war Lebanon. Energy Res. Soc. Sci. 36, 36-43.

AbiYaghi, M.N., Catusse, M., Younes, M., 2017. 'From isqat an nizam at-ta'ifi to the garbage crisis movement: political identities and antisectarian movement. In: Di Peri, R., Meir, D. (Eds.), Lebanon Facing the Arab Uprisings. Palgrave MacMillan UK, London.

Abu-Rish, Z., 2015, September 22. Setting the agenda: electricity in early independence Lebanon. The Lebanese Centre for policy studies. Retrieved from: https://www.lc ps-lebanon.org/agendaArticle.php?id 55. (Accessed 25 July 2019).

AEMS, 2017. The Impact of the Syrian Crisis on the Lebanese Power Sector and Priority Recommendations. Ministry of Energy and Water/UNDP.

Ahmed, Z.U., Julian, C.C., 2012. International entrepreneurship in Lebanon. Glob. Bus. Rev. 13 (1), 25-38. 
Amine, J., 2018, April 16. Wind farms in Lebanon: challenges and opportunities. Executive magazine. Retrieved from: http://www.executive-magazine.com/econom cs-policy/wind-farms-in-lebanon. (Accessed 4 July 2018).

ANND, 2017. Promotion of the private sector at the expense of obstructing sustainable development. Retrieved from: http://www.socialwatch.org/sites/default/files/2017 -SR-LEBANON-eng.pdf. (Accessed 15 August 2018).

AUB Policy Institute, 2018. Lebanon's gas market development and the role of FSRU. The energy policy and security program at the Issam Fares Institute for public policy and international Affairs at AUB. Retrieved from: https://www.aub.edu.lb/ifi/Documen ts/publications/policy_briefs/2018-2019/20181018_lebanon_gas_market_develop ment.pdf. (Accessed 29 August 2019).

Ayoub, M., Boustany, I., 2019. Bankability of a Large-Scale Solar Power Plant in the TfailLebanon. AUB Policy Institute \& The Lebanese Foundation for Renewable Energy. Retrieved from: https://www.aub.edu.lb/ifi/news/Pages/20190522-bankability-la rge-scale-solar-power-plant-tfail-lebanon.aspx. (Accessed 14 August 2019).

Bassil, G., 2010. Policy Paper for the Electricity Sector. Ministry of Energy and Water, Lebanese Republic.

Bellini, E., 2019, May 23. Lebanon's Tufail Region May Host Planned 500 MW Solar Plant. PV Magazine. Retrieved from: https://www.pv-magazine.com/2019/05/23/le banons-tufail-region-may-host-planned-500-mw-solar-plant/?utm_source dlvr. it\&utm_medium twitter. (Accessed 14 August 2019).

Berjawi, A.H., Najem, S., Faour, G., Abdallah, C., Ahmad, A., 2017. Assessing Solar PV's Potential in Lebanon. Issam Fares Institute for Public Policy and International Affairs, American University of Beirut, Lebanon.

Council of Ministers, 2018. Summary of the Electricity Sector in Lebanon. Presentation by Minister of Energy and Water to the Lebanese Council of Ministers, Beirut, Lebanon.

Dziadosz, A., 2018, February 26. Can green energy beat Lebanon's 'Generator Mafias?' bloomberg.. Retrieved from: https://www.bloomberg.com/news/features/ 2018-02-26/can-green-energy-beat-lebanon-s-generator-mafias. (Accessed 4 July 2018)

ECOSOC, 2019. March. Unemployment In Lebanon: Findings And Recommendations. ECOSOC \& GOPA. Retrieved from: http://www.databank.com.lb/docs/Unemp loyment\%20in\%20Lebanon\%20Findings\%20and\%20Recommendations\%202019\% 20ECOSOC.pdf. (Accessed 24 July 2019).

Fardoun, F., Ibrahim, O., Younes, R., Louahlia-Gualous, H., 2012. Electricity of Lebanon problems and recommendations. Energy Procedia 19, 310-320.

Fattouh, B., Mahadeva, L., 2016. Managing oil and gas revenues in Lebanon. The Lebanese center for policy studies. Retrieved from: http://lcps-lebanon.org/publ ications/1472126663-fattouh-lavan_management-paper_eng.pdf. (Accessed 26 July 2019).

Global Entrepreneurship Monitor, 2019. Entrepreneurial behaviours and attitudes. Retrieved from: https://www.gemconsortium.org/data. (Accessed 29 August 2019).

GoL, 2018. Capital investment program. In: Conference Economique Le Developpement par Reformes avec les Entreprises. Report No. L17023-0100D-RPT-PM-01 REV 6, Beirut, Lebanon.

Greenpeace. Greenpeace solar technician program. Retrieved from: https://www.gree npeacearabic.solutions/en-solartechnicians. (Accessed 8 November 2018).

Institute for Global Prosperity, 2019. Transitions to Renewable Energy and Sustainable Prosperity in Lebanon: A People-Centred Approach to Equitable Energy Supply. Institute for Global Prosperity Working Paper Series, University College London. Retrieved from: https://www.ucl.ac.uk/bartlett/igp/research/publications. (Accessed 9 August 2019).

IPPC, 2018. Global warming of 1.5C. Intergovernmental panel on climate change. Retrieved from: http://www.ipcc.ch/report/sr15/. (Accessed 15 October 2018).

IRENA, 2019, March. Renewable energy outlook Lebanon: multi-stakeholder meeting. Retrieved from: https://www.irena.org/events/2019/Mar/Renewable-Energy-Out look-Lebanon-Multi-stakeholder-meeting. (Accessed 8 May 2019).

Jackson, T., 2011. Prosperity without Growth: Economics for a Finite Planet. Routledge, London.

Khoury, J., Mbayed, R., Salloum, G., Guerrero, J., 2016. Review on the integration of photovoltaic renewable energy in developing countries - special attention to the Lebanese case. Renew. Sustain. Energy Rev. 57, 562-575.

Kranz, M., 2019, August 7. Lebanese Dam Project Stirs Earthquake Fears, Environment Concerns. Aljazeera. Retrieved from: https://www.aljazeera.com/indepth/features lebanese-dam-project-stirs-earthquake-fears-environment-concerns-19080708282 8083.html. (Accessed 28 August 2019).

Krastrissianakis, K., Smaira, D., Staeheli, L.A., 2019. "Synthesis Is Not the Same Thing as Uniformity": the Cosmopolitics of Youth Citizenship in Lebanon. Geopolitics. https://doi.org/10.1080/14650045.2019.1639043.

LCEC, 2016. National Renewable Energy Action Plan for the Republic of Lebanon (NREAP) 2016-2020. Ministry of Energy and Water/LCEC, Lebanon.

LCEC, 2017. Call for expression of interest (EOI) to participate in proposal submissions to build solar photovoltaic (PV) farms in Lebanon. Retrieved from: http://lcec.org. lb/Content/uploads/LCECOther/170110120003643 Call\%20for\%20EOI's\%20So lar\%20Farms-\%20090117.pdf. (Accessed 25 September 2018).

LCEC, 2018. Our history. LCEC. Retrieved from: http://www.lcec.org.lb/en/LCEC/About Us/Our-history/5. (Accessed 25 September 2018).

LCEC, 2019. What is NEEREA? LCEC, NEEREA \& WEC. Retrieved from: http://lcec.org. $\mathrm{lb} / \mathrm{en} / \mathrm{NEEREA} /$ AboutUs. (Accessed 25 July 2019).

LCEC, 2019. Solar water heaters. LCEC, NEEREA \& WEC. Retrieved from: http://www. lcec.org.lb/en/LCEC/Projects/23/Solar-Water-Heaters. (Accessed 28 August 2019).

Loveday, D.L., Bhamra, T., Tang, T., Haines, V.J.A., Holmes, M.J., Green, R.J., 2008. The energy and monetary implications of the ' $24 / 7$ ' 'always on' society. Energy Policy 36 (12), 4639-4645.
Machnouk, S., El Houseini, H., Kateb, R., Stephan, C., 2019, July. The energy regulation market review, Edition 8 - Lebanon. The law reviews. Retrieved from: https://thela wreviews.co.uk/edition/the-energy-regulation-and-markets-review-editio n-8/1194563/lebanon. (Accessed 8 August 2019).

Ministry of Environment, 2011. Lebanon's Second National Communication to the UNFCCC. Ministry of Environment, GEF \& UNDP. Retrieved from: http://climatech ange.moe.gov.lb/viewfile.aspx?id 19. (Accessed 24 July 2019).

Ministry of Foreign Affairs of the Netherlands, 2018. Climate change profile: Lebanon. Retrieved from: https://reliefweb.int/report/lebanon/climate-change-profile-leba non. (Accessed 28 August 2019).

Moore, H.L., 2015. Global prosperity and sustainable development goals. J. Int. Dev. 27 (6), 801-815.

OECD/IEA, 2014. Energy Imports, Net (\% of Energy Use). IEA Statistics. Retrieved from: https://data.worldbank.org/indicator/EG.IMP.CONS.ZS?locations LB. (Accessed 30 November 2018)

Rose, S., 2018. November 8. Lebanese Government Tries to Rein in Billion-Dollar 'generator Mafias'. The National. Retrieved from: https://www.thenational.ae/worl d/mena/lebanese-government-tries-to-rein-in-billion-dollar-generator-mafias -1.789451. (Accessed 26 July 2019).

Shi, D., Wang, L., Wang, Z., 2019. What affects individual energy conservation behavior: personal habits, external conditions or values? An empirical study based on a survey of college students. Energy Policy 128, 150-161.

Stel, N., Naude, W., 2016. Public-private entanglement: entrepreneurship in Lebanon's hybrid political order. J. Dev. Stud. 52 (2), 254-268.

Stiglitz, L., Sen, A., Fitoussi, J.-P., 2010. Measuring Our Lives: Why GDP Doesn't Always Add up. New Press, New York.

The Business Year, 2017. A powerful role. Retrieved from: https://www.thebusinessyear. com/lebanon-2017/a-powerful-role/roundtable. (Accessed 30 August 2018).

The Daily Star, 2018, March 30. Jobless Rate at 46 Pct, President Warns. The Daily Star. Retrieved from: http://www.dailystar.com.lb/Business/Local/2018/Mar-30/44361 3-jobless-rate-at-46-pct-president-warns.ashx. (Accessed 24 July 2019).

UN, E.S.C.W.A., 2018. United Nations Development Account Project in Promoting Renewable Energy Investments for Climate Change Mitigation and Sustainable Development: Case Study on Policy Reforms to Promote Renewable Energy in Lebanon. United Nations, Beirut, Lebanon.

UNDP, 2017. Lebanon: Derisking Renewable Energy Investment. United Nations Development Programme, New York, NY.

UNDP, 2019. Goal 13: Climate Action. UNDP Lebanon. Retrieved from: http://www.lb. undp.org/content/lebanon/en/home/sustainable-development-goals/goal-13-clima te-action.html. (Accessed 28 August 2019).

UNDP, 2019. Goal 9: Industry, Innovation and Infrastructure. UNDP. Retrieved from: https://www.undp.org/content/undp/en/home/sustainable-development-goals/go al-9-industry-innovation-and-infrastructure.html. (Accessed 27 July 2019).

UNDP-GEF, 2014. Lebanon's first national survey study of the solar water heater market. Retrieved from: http://www.cedro-undp.org/content/uploads/publicati on/141204025125965 LCECCEDRO2014.Lebanon'sNationalSurveyStudyofthe SHWandPVMarkets.pdf. (Accessed 28 August 2019).

UNDP-DREG, 2018. The 2017 solar PV status report for Lebanon. MoEW, LCEC, UNDP \& GEF. Retrieved from: http://www.lb.undp.org/content/dam/lebanon/docs/Energy \%20and\%20Environment/2017\%20Solar\%20PV\%20Status\%20Report\%20for\%20 Lebanon.pdf. (Accessed 8 March 2019).

UNDP-CEDRO, 2015. Willingness to Pay for Renewable Energy the Case of the Lebanese Residential and Commercial Sectors. Retrieved from: http://www.cedro-undp. org/content/uploads/publication/151001020846014 RenewableEnergyRepo rt-HR.pdf. (Accessed 5 July 2018).

UNDP-CEDRO, 2018. Energy Efficient Home Appliances: Perspectives from Lebanese Consumers. UNDP-CEDRO, Beirut, Lebanon.

UNDP-CEDRO, 2018. Sustainable Energy for Lebanese Villages and Communities: the Village 24 Initiative. UNDP-CEDRO, Beirut, Lebanon.

UNDP-CEDRO, 2019. Prioritization and assessment of value chains within the renewable energy sector in Lebanon. MoEW, Kingdom of The Netherlands \& UNDP. Retrieved from: http://www.cedro-undp.org/conte nt/uploads/publication/190802113500611 ValueChain.pdf. (Accessed 8 August 2019).

UNRWA, 2014. Where we work. UNRWA. Retrieved from: https://www.unrwa.org/wher e-we-work/lebanon. (Accessed 23 July 2018).

Verdeil, E., 2016. Beirut, Metropolis of darkness: the politics of urban electricity grids. In: Luque-Ayala, A., Silver, J. (Eds.), Energy, Power and Protest on the Urban Grid: Geographies of the Electric City. Routledge, London and New York, pp. 155-175.

Von Borgstede, C., Andersson, M., Johnsson, F., 2013. Public attitudes to climate change and carbon mitigation-implications for energy-associated behaviours. Energy Policy 57, 182-193.

World Bank, 2019. Lebanon Electricity Transmission Project P170769. World Bank. Retrieved from: http://documents.worldbank.org/curated/en/235831562864951 356/text/Concept-Project-Information-Document-PID-Lebanon-Electricity-Tra nsmission-Project-P170769.txt. (Accessed 28 August 2019).

Yassin, N., 2018. 101 Facts \& Figures on the Syrian Refugee Crisis. UNHCR \& Issam Fares Institute for Public Policy and International Affairs, American University Beirut. Retrieved from: https://data2.unhcr.org/en/documents/download/70359. (Accessed 24 July 2019).

Youth Policy. Middle East and North Africa: youth facts. Retrieved from: http://www.yo uthpolicy.org/mappings/regionalyouthscenes/mena/facts/. (Accessed 23 August 2018). 